\title{
Physicochemical, cooking quality and sensory characterization of yellow alkaline noodle: impact of mango peel powder level
}

\author{
${ }^{1}$ Nur Azura, Z., ${ }^{1,{ }^{*}}$ Radhiah, S., ${ }^{2}$ Wan Zunairah, W.I., ${ }^{2}$ Nurul Shazini, R., ${ }^{1}$ Nur Hanani, Z.A. \\ and ${ }^{1}$ Ismail-Fitry, M.R. \\ ${ }^{1}$ Department of Food Technology, Faculty of Food Science and Technology, Universiti Putra Malaysia, \\ 43400 UPM Serdang, Selangor, Malaysia \\ ${ }^{2}$ Department of Food Science, Faculty of Food Science and Technology, Universiti Putra Malaysia, 43400 \\ UPM Serdang, Selangor, Malaysia
}

Article history:

Received: 25 April 2019

Received in revised form: 4

June 2019

Accepted: 4 June 2019

Available Online: 11 June 2019

\section{Keywords:}

Mango peel,

Yellow alkaline noodle,

Fibre,

Texture,

Sensory

DOI:

https://doi.org/10.26656/fr.2017.4(1).170

\begin{abstract}
Mango peel comprises of $7-25 \%$ of mango fruit that contributes to the environmental pollution. Mango peel contains nutraceutical compounds that are useful as a functional ingredient to increase nutritional properties in Asian staple food, which in our case was yellow alkaline noodle. The objective of this research was to study the effect of mango peel powder at different levels $(0 \%, 10 \%, 20 \%$, and $30 \%)$ on the cooking, physicochemical and sensory properties of yellow alkaline noodles (YAN). Substitution of wheat flour with mango peel powder significantly increased 2 to 15 times fibre content in the YAN compared to control. Additionally, fat and carbohydrate were reduced by $8-45 \%$ and 6-25\%, respectively. The lowest cooking quality was observed in YAN incorporated with $30 \%$ mango peel powder, which showed the highest cooking lost $(20.45 \%)$ and the lowest cooking yield (163.7\%). YAN with mango peel powder had decreased lightness $\left(\mathrm{L}^{*}\right)$ and yellowness $\left(\mathrm{b}^{*}\right)$. All of the texture profile was negatively affected by an increment of mango peel powder in YAN but showed no significant differences. Sensory attributes of YAN with the incorporation of mango peel powder up to $20 \%$ showed similar acceptance with the control. The YAN with $30 \%$ mango peel powder had significantly lower sensory acceptance of panelists than other YAN samples. The study suggests that mango peel powder substitution up to $20 \%$ is suitable to increase nutritional properties of YAN with minimal adverse effects on the cooking quality, textural properties and sensory attributes.
\end{abstract}

\section{Introduction}

The by-products of fruit processing is a huge concern because it contributes to environmental pollution as waste. Some of these waste can be processed into flour and used as functional ingredients in food applications (Sogi et al., 2005). Asia accounts for $77 \%$ of global mango production with $35-60 \%$ by-products (peel and kernel). Mango peel consists of $7-24 \%$ of the total weight of mango fruit (Iqbal et al., 2009; Kim et al., 2012). It has much beneficial uses in food and pharmaceutical industries. Mango peel has high dietary fibre, pectin, polyphenols and carotenoids (Ajila et al., 2010; Ajila and Prasada Rao, 2013; Siriamornpun et al., 2016). Therefore, mango peel may improve the nutritional value of food products with lower nutritional value, for example, yellow alkaline noodles.

Being one of the staple foods in Asia, noodles are rich in carbohydrate but lack of other essential nutritional components (Li et al., 2012). Noodles are made from 60$70 \%$ white wheat flour that is low in essential nutrients (mostly minerals, vitamins and fibre) due to wheat milling (Choo and Aziz, 2010). Other minor ingredients in noodle-making are water and salt. Some noodles, like yellow alkaline noodles (YAN) has additional minor ingredient of alkaline salt that is combined with sodium chloride to give a distinct taste and yellow colour (Hatcher et al., 2009). However, the rise in healthconscious consumers also increased the demand for wheat-based product with added nutritional value. Hence, the nutrients deficiency in YAN can be compensated by adding high nutritional value by-product of fruit processing, specifically mango peel.

Mango peel powder is used as a functional ingredient in a variety of food products such as biscuits, bread and sponge cakes (Aziz et al., 2012). The 
incorporation of $2.5 \%$ and $5 \%$ mango peel powder improved the nutritional quality of macaroni without affecting it's cooking quality, textural or sensory properties (Ajila et al., 2010). In soft dough biscuits, mango peel powder enhanced phenolic content and carotenoid content, total dietary fibre, soluble dietary fibre and insoluble dietary fibre of the biscuits. However, the biscuits had higher breaking strength, whereas the crust colour and appearance of biscuit incorporated with up to $10 \%$ mango peel powder were similar as the control (Ajila et al., 2008). Mango peel powder also reduced retrogradation and lipid oxidation of normal and glutinous rice flours due to the interactions of phenolic compounds with amylopectin molecules in mango peel powder, resulting in a softer texture of the rice flour food (Siriamornpun et al., 2016).

With an exception to a study by Ajila et al. (2010), the studies on incorporation of mango peel powder in food were limited to only bakery products (Ajila et al., 2008; Ashoush and Gadallah, 2011). Due to increasing demands of healthier Asian food products, it is of our interest to find the optimum amount of mango peel powder in YAN that will significantly improve the nutritional properties, but yet minimize the negative impact on the textural and sensorial properties. Hence, the objective of this study was to determine the physicochemical properties, cooking quality and consumer's acceptance on YAN added with different levels of mango peel powder. This study shows good potential in producing food with higher nutritional values by incorporating agricultural by-products, therefore, turning waste into health.

\section{Materials and methods}

\subsection{Materials}

Ripe mangoes (Mangifera indica L.), variety of Susu (MA 224) were obtained from Seri Kembangan, Selangor. The ripening stage of mangoes was 7 days under natural condition for ripe green stage mango. Wheat flour, salt, sodium carbonate and cooking oil were obtained from a local grocery store. All chemicals used were reagent grade.

\subsection{Preparation of mango peel powder}

Mangoes were peeled, washed using water and evenly spread on the tray. The mango peels were dried at $50.0 \pm 2.0^{\circ} \mathrm{C}$ by using a smoke dryer for $24 \mathrm{hrs}$. The dried mango peels were finely ground into powder by using a dry blender (Model MX-GM1011, Panasonic, Malaysia) and sieved through a $150 \mu \mathrm{m}$ sieve.

\subsection{Preparation of yellow alkaline noodle}

Four formulations of YAN were prepared (Table 1). Wheat flour was substituted by $0 \%$ (control), $10 \%, 20 \%$ and $30 \%$ mango peel powder. Firstly, wheat flour and mango peel powder were sieved together and mixed at low speed for $20 \mathrm{~s}$ using a mixer (Kitchen Aid, USA). Then, salt and sodium carbonate were dissolved in water and added into the flour mixture, mixed for $1 \mathrm{~min}$ at a low speed and followed by an intermediate speed for 4 mins. The dough was divided into sections and each section was passed through two rotating rollers (Shule, Changzhou, Jiangsu, China) to form a sheet. The sheet was folded and passed through the rollers six times before cutting it into noodle strands. Then, the noodle was cooked in boiling water $\left(98.0 \pm 0.5^{\circ} \mathrm{C}\right)$ for $50 \mathrm{~s}$. The noodle was immediately cooled under tap water for 1 min, drained and cooled to room temperature.

Table 1. Formulation of yellow alkaline noodle (YAN)

\begin{tabular}{|c|c|c|c|c|}
\hline \multirow{2}{*}{ Ingredients } & \multicolumn{4}{|c|}{ Substituted mango peel powder in YAN (\%) } \\
\hline & 0 & 10 & 20 & 30 \\
\hline Wheat flour (g) & 651 & 551 & 451 & 351 \\
\hline $\begin{array}{l}\text { Mango Peel } \\
\text { Powder (g) }\end{array}$ & - & 100 & 200 & 300 \\
\hline Water (mL) & 300 & 300 & 300 & 300 \\
\hline Salt (g) & 17 & 17 & 17 & 17 \\
\hline $\begin{array}{l}\text { Sodium } \\
\text { carbonate (g) }\end{array}$ & 17 & 17 & 17 & 17 \\
\hline $\begin{array}{l}\text { Cooking oil } \\
(\mathrm{mL})\end{array}$ & 15 & 15 & 15 & 15 \\
\hline
\end{tabular}

\subsection{Nutritional analysis}

Moisture content, crude fibre, protein, fat and ash were analysed based on AOAC 977.11, AOAC 962.09, AOAC 955.04, AOAC 960.39 and AOAC 923.03, respectively (AOAC, 2016). The carbohydrate content of the noodles was calculated by subtracting $100 \%$ with moisture content, crude fibre, protein, fat and ash.

\section{$2.5 \mathrm{pH}$}

The $\mathrm{pH}$ of YAN was measured according to Yeoh et al. (2014). Cooked YAN (10 g) was mixed with deionized water $(100 \mathrm{~mL})$ for 5 mins and left to stand for $30 \mathrm{~min}$. Then, the mixture was filtered and the $\mathrm{pH}$ of the filtrate was measured using a $\mathrm{pH}$ meter (Mettler-Toledo, S40 SevenMultiTM, Switzerland).

\subsection{Cooking quality}

\subsubsection{Cooking yield}

The cooking yield was determined according to Tan et al. (2016). The partially cooked YAN (10 g) was placed in deionized water $(150 \mathrm{~mL})$ and boiled for 4 mins (optimal cooking time). Then, water was drained, and YAN was left to cool for 15 mins before weight measurement. The cooking yield was calculated using 
the following equation:

$$
\text { Cooking yield }(\%)=(\mathrm{WA} / \mathrm{WB}) \times 100
$$

Where WA is the weight of noodles after cooking (g) and WB is the weight of noodles before cooking (g).

\subsubsection{Cooking loss}

The cooking loss was determined according to Tan et al. (2016). Pre-dried $250 \mathrm{~mL}$ beaker was cooled in a desiccator and weighed. The water from cooking yield measurement was poured into the pre-dried beaker and dried in an oven at $105^{\circ} \mathrm{C}$ for $24 \mathrm{hrs}$ or until a constant weight was achieved. The beaker containing the dried residue was weighed after cooling in a desiccator. The cooking loss was calculated using the following equation:

$$
\text { Cooking loss }(\%)=((\mathrm{WR}-\mathrm{WB}) / \mathrm{WS}) \times 100
$$

Where WR is the total weight of beaker and dried residue $(\mathrm{g})$, WB is the weight of pre-dried beaker $(\mathrm{g})$, and WS is the weight of noodle before cooking $(\mathrm{g})$.

\subsection{Colour measurement}

Colour of freshly cooked YAN was analysed using colorimeter (Konica Minolta, CM3500d, Japan) by placing the measuring head at the individual piece of noodles. The colour was measured as lightness ( $\left.\mathrm{L}^{*}\right)$, redness $\left(\mathrm{a}^{*}\right)$, and yellowness $\left(\mathrm{b}^{*}\right)$ hues.

\subsection{Texture profile}

Texture profile analysis of YAN was determined using a texture analyzer (Stable Micro Systems, TATX2, UK). The analysis was performed with a cylindrical probe (diameter $35 \mathrm{~mm}$ ) to compress the samples to $50 \%$ of their original height. The crosshead pre-test speed was set at $5 \mathrm{~mm} / \mathrm{s}$, while the test speed and post-test speed were set at $1 \mathrm{~mm} / \mathrm{s}$. The clearance between top compression plate and the base was set at 20 $\mathrm{mm}$ and a $5 \mathrm{~kg}$ maximum load cell was used. Two strands of cooked noodle samples were placed parallel on the middle of the compression plate, and two continuous compressions were carried out.

\subsection{Sensory evaluation}

Hedonic test was carried on YAN based on the 9 point hedonic scale ( 1 - extremely dislike, 5 - neither like or dislike, 9 - extremely like) (Li et al., 2013). A total of thirty untrained panellists from Universiti Putra Malaysia with the age range of 20-35 were served in a randomized order with $5 \mathrm{~cm}$ pieces of each YAN formulations. They were instructed to rinse their mouth after each sampling. The YAN was evaluated on the taste, colour, hardness, smoothness, springiness, appearance and overall acceptability.

\subsection{Statistical analysis}

The means were expressed from three replicates unless stated otherwise. The results were analysed by one-way analysis of variance (ANOVA), followed by Tukey's test using the confidence level of $0.95(\mathrm{p}<0.05)$. The statistical analyses were conducted using Minitab version 17 for Windows.

\section{Results and discussion}

3.1 Effect of mango peel powder on the nutritional composition of YAN

Table 2 shows that mango peel powder had significantly higher ash (14 times), fat (1.5 times) and crude fibre (86 times) than wheat flour. The fibre in mango peel powder was mainly from cellulose, hemicellulose and pectin (Sogi et al., 2013). On the contrary, protein and carbohydrate in mango peel powder were significantly lower than the wheat flour. The nutritional composition of mango peel powder was similar with those reported by Aziz et al. (2012) but differed in terms of fat, protein and carbohydrate in mango peel powder from Badami and Raspuri varieties (Ajila et al., 2008). The difference was probably due to the varietal difference, climate differences, topographic locations, soil type, fruit maturity stage and the agronomic practices (Imran et al., 2013).

With exception to ash and protein, other

Table 2. Compositions of mango peel powder, wheat flour and yellow alkaline noodles

\begin{tabular}{lcccccc}
\hline \multirow{2}{*}{ Composition } & Mango Peel & \multirow{2}{*}{$\begin{array}{c}\text { Powder } \\
\end{array}$} & Wheat Flour & \multicolumn{4}{c}{ Substituted mango peel powder in YAN (\%) } \\
\cline { 4 - 7 } & & 0 & 10 & 20 & 30 \\
\hline Moisture (\%) & $10.66 \pm 0.03^{\mathrm{d}}$ & $10.99 \pm 0.90^{\mathrm{d}}$ & $52.93 \pm 3.38^{\mathrm{c}}$ & $55.33 \pm 0.84^{\mathrm{bc}}$ & $59.70 \pm 1.95^{\mathrm{ab}}$ & $64.33 \pm 2.42^{\mathrm{a}}$ \\
Ash (\%) & $2.88 \pm 0.17^{\mathrm{a}}$ & $0.20 \pm 0.06^{\mathrm{c}}$ & $0.54 \pm 0.14^{\mathrm{b}}$ & $0.57 \pm 0.14^{\mathrm{b}}$ & $0.60 \pm 0.04^{\mathrm{b}}$ & $0.65 \pm 0.14^{\mathrm{b}}$ \\
Fat (\%) & $3.43 \pm 0.99^{\mathrm{a}}$ & $2.24 \pm 0.61^{\mathrm{ab}}$ & $2.65 \pm 0.54^{\mathrm{a}}$ & $2.43 \pm 0.54^{\mathrm{a}}$ & $2.23 \pm 0.43^{\mathrm{a}}$ & $1.46 \pm 0.31^{\mathrm{b}}$ \\
Protein (\%) & $1.04 \pm 0.47^{\mathrm{c}}$ & $8.44 \pm 1.04^{\mathrm{a}}$ & $5.02 \pm 0.84^{\mathrm{b}}$ & $4.92 \pm 0.66^{\mathrm{b}}$ & $4.46 \pm 0.49^{\mathrm{b}}$ & $3.83 \pm 1.84^{\mathrm{b}}$ \\
Crude Fibre (\%) & $10.36 \pm 3.98^{\mathrm{a}}$ & $0.12 \pm 0.03^{\mathrm{b}}$ & $0.05 \pm 0.00^{\mathrm{c}}$ & $0.11 \pm 0.03^{\mathrm{c}}$ & $0.41 \pm 0.20^{\mathrm{b}}$ & $0.76 \pm 0.09^{\mathrm{a}}$ \\
Carbohydrate (\%) & $71.63 \pm 3.81^{\mathrm{b}}$ & $78.02 \pm 0.99^{\mathrm{a}}$ & $38.81 \pm 4.36^{\mathrm{c}}$ & $36.63 \pm 1.13^{\mathrm{cd}}$ & $32.59 \pm 2.77^{\mathrm{cd}}$ & $28.98 \pm 3.89^{\mathrm{d}}$ \\
\hline
\end{tabular}

Values are expressed as mean \pm standard deviation. Same alphabet superscript in the row are not significantly different ( $<<0.05$ ). Except moisture, other compositions are dry basis. 
compositions in YAN had significant changes with an increment of mango peel powder in YAN (Table 2). Replacement of wheat flour with 30\% mango peel powder showed prominent changes in YAN compared to $10 \%$ and $20 \%$ mango peel powder in YAN. Moisture content in YAN was $17.7 \%$ higher than control at $30 \%$ substitution. This was attributed to the high water absorption capacity of pectin in the mango peel powder (Goswami et al., 2017). On the contrary, fat content in YAN substituted with $30 \%$ mango peel powder reduced significantly by $45 \%$ compared to control. According to Mellema (2003) and Ho and Che Dahri (2016), the moisture content in food affected the fat uptake of the food because water molecules in YAN act as a protective barrier that prevents fat absorption from oil coating of YAN. This phenomenon was observed in YAN with $30 \%$ mango peel powder that depicted the highest moisture and lowest fat contents than other samples.

The crude fibre in YAN increased significantly with the replacement of $20 \%$ and $30 \%$ mango peel powder. The result was expected because mango peel powder showed fibre content of $10.36 \%$, as compared to wheat flour of only $0.12 \%$. The trend was similar to Ajila et al. (2010), where insoluble dietary fibre and total dietary fibre in macaroni increased significantly with an increasing amount of mango peel in the formulation. According to Ajila et al. (2008), mango peel is rich with fibre that consists of $19.0 \%$ soluble dietary fibre, $32.1 \%$ insoluble dietary fibre and $51.2 \%$ total dietary fibre. The crude fibre in YAN showed a negative correlation with carbohydrate results. Higher amount of fibre is often associated in decrease of carbohydrate content, as depicted in the result. The YAN with $30 \%$ mango peel powder showed a significant $25.3 \%$ decrease of carbohydrate compared to control.

\subsection{Effect of mango peel powder on the cooking quality and $\mathrm{pH}$ of $Y A N$}

Cooking quality of YAN was reflected by the cooking loss and cooking yield of YAN (Table 3). With the increased substitution of mango peel powder, cooking loss also showed a significant increase, whereas cooking yield was prominently lower at $30 \%$ substitution of mango peel powder. The inversed correlation of cooking and cooking yield was also observed by Ajila et al. (2010) that replaced wheat flour with mango peel powder in macaroni. Similarly, incorporation of linseed into noodle showed an increase in the cooking loss of noodle (Zhu and Li, 2019). Diminished cooking quality of YAN with $30 \%$ mango peel powder was confirmed when it had optimum cooking time of only $2 \mathrm{mins}$, as compared to the control of 3.38 mins.

Replacing wheat flour with mango peel powder caused two major compositional changes that negatively affected the cooking quality of YAN. The first change was dilution of protein content in YAN, as observed in Table 2. The protein dilution caused lower amount of gluten formation during production of YAN that affected the stability of structural density and water holding capacity of YAN. Cooking loss was correlated with the structural densities of surfaces, where the soluble solids were eluted from the surface into the cooking water (Kang et al., 2017). The second compositional change in YAN was the significant increase in fibre content (Table 2). According to (Ajila et al., 2010), fibre in mango peel powder changes the gluten protein network and disrupts protein-starch matrix. They also claimed that fibre caused uneven distribution of water within the matrix due to the competitive hydration tendency of fibre. These two compositional changes caused YAN incorporated with mango peel powder to be less resilient towards heat and leached out more soluble solids.

Typically, the $\mathrm{pH}$ of YAN is in alkaline range due to the addition of sodium carbonate. Alkaline reagents function to give the favourable yellow colour (Kubomura, 1998) and increase the chewiness and hardness of noodles (Shin and Kim, 1993). Significant reduction of $\mathrm{pH}$ occurred with an increasing amount of mango peel added into YAN. The decrease was due to the acidity of mango peel powder with the $\mathrm{pH}$ of 4.0 (Banerjee et al., 2016) which was lower than $\mathrm{pH}$ of wheat flour that ranges from 6.0 to 6.8 (Moss et al., 1986). The previous study found that the addition of banana pulp and banana peel flour also reduced the $\mathrm{pH}$ of YAN (Foo et al., 2011) due to the lower pH of banana pulp and banana peel flour.

\subsection{Effect of mango peel powder on the colour of YAN}

YAN is favourable as yellow-coloured noodles that are achieved by the addition of alkaline reagents in the noodle-making process. In this study, the alkaline reagent used was sodium carbonate (Table 1). But substituting wheat flour with mango peel powder affected the overall colour characteristics of YAN (Figure 1). With a higher amount of mango peel powder in YAN, lightness and yellowness decreased significantly, especially at $30 \%$ substitution. However, redness increased significantly at $10 \%$ substitution, then reduced gradually with $20 \%$ and $30 \%$ substitution. At $10 \%$ mango peel powder in YAN, the brown colour of mango changed the yellow colour of YAN to red hue. But as the amount of mango peel powder increased in YAN, the brown colour of YAN intensified, therefore reducing the redness. Similarly, Ajila et al. (2008) observed decreased lightness and yellowness in biscuits that were incorporated with $0-20 \%$ mango peel powder. They claimed that the polyphenols in mango peel were 
oxidized by polyphenol oxidase and peroxidase possible, consequently changing the yellow mango peel powder into brown colour. Hence, the brown colour affected the overall colour changes in YAN.

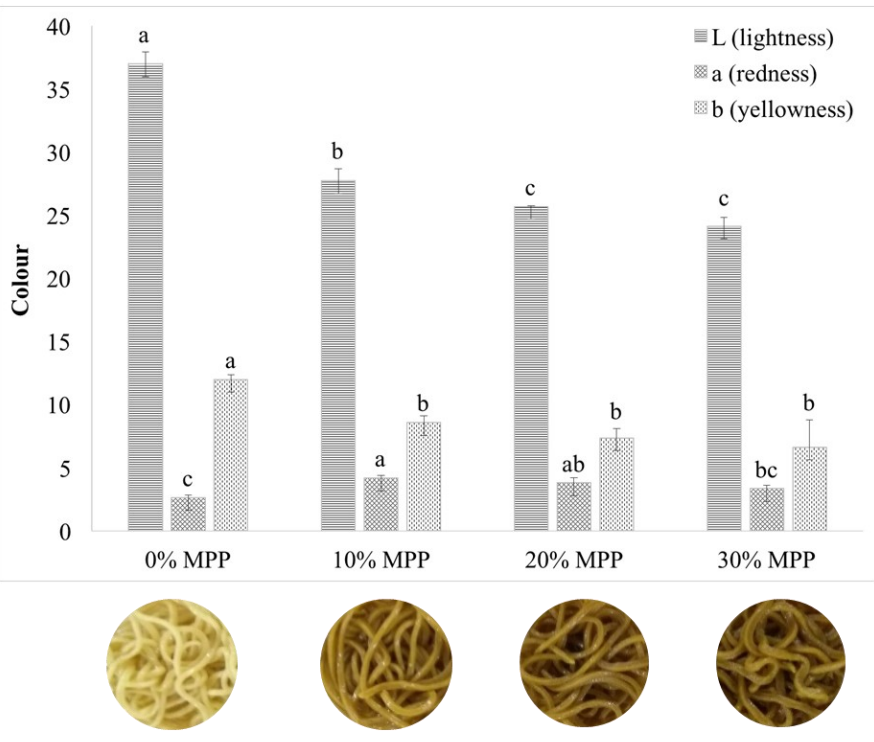

Figure 1. Colour measurements of yellow alkaline noodle (YAN). Values are expressed as mean \pm standard deviation. Same letter within bar for each treatment are not significantly different $(\mathrm{p}<0.05)$.

\subsection{Effect of mango peel powder on the texture of YAN}

Table 3 shows the summary of the textural properties of YAN. Although the results showed no significant differences in all of the textural properties, the hardness showed an unusual trend. Substitution of mango peel powder up to $20 \%$ in YAN increased the hardness, but $30 \%$ mango peel powder reduced the hardness by $9 \%$ as compared to the control YAN. The same trend was observed in the chewiness of YAN. These results are likely to be related to the higher moisture in YAN supplemented with mango peel powder (Table 2). The fibre content in mango peel powder had more hydroxyl groups that probably caused higher water absorption (Sudha et al., 2007), leading to extensive gluten structure that harden the texture of YAN. However, the higher amount of mango peel powder diluted the amount of gluten in YAN, weakening gluten-starch interaction and lowering viscoelasticity that softens the texture of YAN.

\subsection{Effect of mango peel powder on the sensory attributes of $Y A N$}

Figure 2 presents the appearance, colour, hardness, smoothness, springiness, taste and overall acceptability of cooked YAN incorporated with mango peel powder. The sensory evaluation was performed using a 9-point hedonic scale. The parameter that scored higher than 5 were considered acceptable. Enriching YAN up to 20\% mango peel powder showed no significant differences on all the sensory parameters. The high standard deviations showed that the panellists had a wider array of preferences towards acceptability of YAN. However, it was notable that YAN with $30 \%$ mango peel powder had the lowest scores in all attributes. Appearance, colour and taste of YAN with $30 \%$ mango peel powder showed lower scores than 5 points.

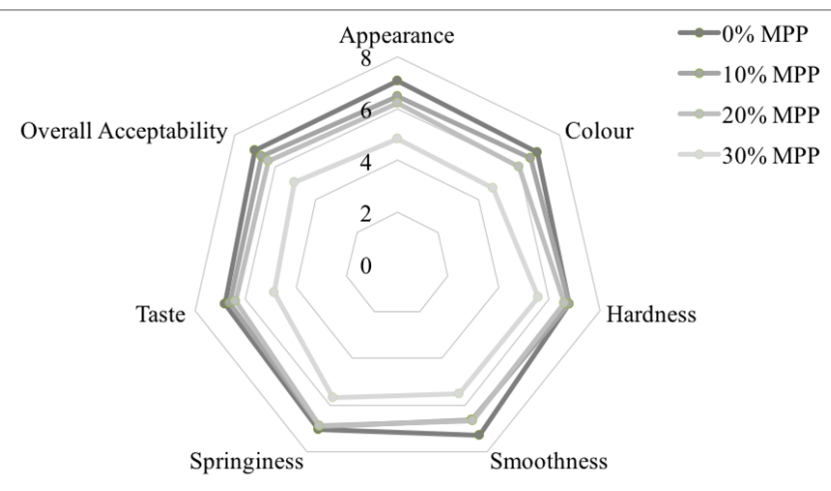

Figure 2. Sensory evaluation of yellow alkaline noodle (YAN) with 0-30\% substituted mango peel powder (MPP).

The result shows that a higher amount of mango peel powder was detrimental to the sensory attributes. These results are consistent with those of Ajila et al. (2010), who observed the lowest sensory evaluation scores of macaroni with the highest amount of mango peel powder incorporated (7.5\%). In their case, taste and overall acceptability of the macaroni were significantly affected, whereas colour and texture were similar to the control. Although the latter study had similar trend with our study, the sensory attributes of macaroni in their study were not severely affected as YAN in our study, most probably because of the lesser amount of mango peel powder $(7.5 \%)$ used. Another possible reason was that macaroni was prepared using durum wheat, a variety of wheat that has harder texture and higher protein content $(12.3 \%)$ than the hard wheat flour $(8.4 \%$ protein) used in our study.

The nutritional properties, cooking quality and texture profile of YAN with $30 \%$ mango peel powder in this study supported the low scores of all of the sensory parameters. Although nutritionally improved with higher fibre, lower fat and lower carbohydrate contents (Table 2), YAN incorporated with $30 \%$ YAN had the lowest protein content. Lacking protein in YAN leads to less formation of gluten, consequently producing noodles with weaker texture and lower resilient towards heat. This was observed in the cooking quality and texture profile of YAN (Table 3). All of these results were affecting the final outcome of the product - a less appealing appearance and low values in hardness, smoothness and springiness.

Colour showed the lowest score in YAN with 30\% mango peel powder because consumers prefer the bright yellow colour of YAN (Tan et al., 2016). The taste of 
Table 3. The $\mathrm{pH}$, texture profile and cooking quality of yellow alkaline noodle (YAN)

\begin{tabular}{lcccc}
\hline & \multicolumn{3}{c}{ Substituted mango peel powder in YAN (\%) } \\
\cline { 2 - 5 } & 0 & 10 & 20 & 30 \\
\hline pH & $9.67 \pm 0.01^{\mathrm{a}}$ & $8.84 \pm 0.11^{\mathrm{b}}$ & $8.45 \pm 0.03^{\mathrm{c}}$ & $8.22 \pm 0.01^{\mathrm{d}}$ \\
Cooking quality & & & & \\
Cooking loss (\%) & $12.35 \pm 0.15^{\mathrm{d}}$ & $15.68 \pm 0.34^{\mathrm{c}}$ & $18.76 \pm 0.62^{\mathrm{b}}$ & $20.45 \pm 0.48^{\mathrm{a}}$ \\
Cooking yield (\%) & $204.8 \pm 29.00^{\mathrm{a}}$ & $196.10 \pm 20.40^{\mathrm{a}}$ & $183.51 \pm 13.88^{\mathrm{a}}$ & $163.73 \pm 0.85^{\mathrm{b}}$ \\
Optimum cooking time (min) & $3.38 \pm 0.08^{\mathrm{a}}$ & $3.20 \pm 0.23^{\mathrm{a}}$ & $2.30 \pm 0.15^{\mathrm{b}}$ & $2.00 \pm 0.37^{\mathrm{b}}$ \\
Texture Profile & & & & \\
Hardness (g) & $19209 \pm 1615^{\mathrm{a}}$ & $19497 \pm 2312^{\mathrm{a}}$ & $19588 \pm 2915^{\mathrm{a}}$ & $17478 \pm 4669^{\mathrm{a}}$ \\
Adhesiveness (g.sec) & $-668 \pm 229^{\mathrm{a}}$ & $-1042.2 \pm 58.6^{\mathrm{a}}$ & $-756 \pm 217^{\mathrm{a}}$ & $-542 \pm 174^{\mathrm{a}}$ \\
Springiness & $0.65 \pm 0.05^{\mathrm{a}}$ & $0.74 \pm 0.05^{\mathrm{a}}$ & $0.61 \pm 0.09^{\mathrm{a}}$ & $0.60 \pm 0.16^{\mathrm{a}}$ \\
Cohesiveness & $0.55 \pm 0.05^{\mathrm{a}}$ & $0.59 \pm 0.01^{\mathrm{a}}$ & $0.61 \pm 0.07^{\mathrm{a}}$ & $0.60 \pm 0.04^{\mathrm{a}}$ \\
Chewiness & $6853 \pm 1306^{\mathrm{a}}$ & $8564 \pm 1425^{\mathrm{a}}$ & $7416 \pm 2195^{\mathrm{a}}$ & $6608 \pm 3224^{\mathrm{a}}$ \\
\hline
\end{tabular}

Values are expressed as mean \pm standard deviation. Same alphabet superscript in the row are not significantly different ( $<<0.05$ ).

YAN with $30 \%$ mango peel powder was also expected to have a much lower preference among panellists due to the undesirable bitter taste of polyphenol that existed in mango peel powder. Ajila et al. (2008) showed the lowest score for the taste of biscuit with $20 \%$ mango peel powder, indicating the prevalence of polyphenol in mango peel powder as the cause. Assuming that all the panellists had similar prior experience in eating yellow noodles, the texture of YAN with $30 \%$ mango peel powder could also play a role in affecting the lower score given to taste because the overall chewing sensation of the mushier texture was not common in YAN. Taking into account all of the low scores given for YAN with $30 \%$ mango peel powder, it was expected that the overall acceptability of the sample was the lowest but was not significant than the other samples.

\section{Conclusion}

Mango peel powder increased the fibre and lowered the fat and carbohydrate contents in YAN. The cooking quality, textural properties and sensory evaluation of YAN were acceptable up to $20 \%$ incorporation of mango peel powder. This study shows that usage of mango peel powder in Asian staple food has potential in improving the nutritional properties of the final product with good consumer acceptance. This will impart healthier food choices, consequently improving the health status of the community. For future research, a study on antioxidant properties of YAN is recommended, as mango peel powder was proven to have sufficient amount of polyphenols and carotenoids.

\section{Acknowledgements}

The author acknowledges the financial support by the Faculty of Food Science and Technology, Universiti Putra Malaysia for this research.

\section{References}

Ajila, C. M. and Prasada Rao, U.J.S. (2013). Mango peel dietary fibre: Composition and associated bound phenolics. Journal of Functional Foods, 5(1), 444450. https://doi.org/10.1016/j.jff.2012.11.017

Ajila, C.M., Aalami, M., Leelavathi, K. and Prasada Rao, U.J.S. (2010). Mango peel powder: A potential source of antioxidant and dietary fiber in macaroni preparations. Innovative Food Science and Emerging Technologies, 11(1), 219-224. https:// doi.org/10.1016/j.ifset.2009.10.004

Ajila, C.M., Leelavathi, K. and Prasada Rao, U.J.S. (2008). Improvement of dietary fiber content and antioxidant properties in soft dough biscuits with the incorporation of mango peel powder. Journal of Cereal Science, 48(2), 319-326. https:// doi.org/10.1016/j.jcs.2007.10.001

AOAC. (2016). Official Methods of Analysis of AOAC International, Gaithersburg, Maryland: AOAC International.

Ashoush I.S. and Gadallah M.G.E. (2011). Utilization of Mango Peels and Seed Kernels Powders as Sources of Phytochemicals in Biscuit. World Journal of Dairy and Food Sciences, 6(1), 35-42.

Aziz, N.A.A., Wong, L.M., Bhat, R. and Cheng, L.H. (2012). Evaluation of processed green and ripe mango peel and pulp flours (Mangifera indica var. Chokanan) in terms of chemical composition, antioxidant compounds and functional properties. Journal of the Science of Food and Agriculture, 92 (3), 557-563. https://doi.org/10.1002/jsfa.4606

Banerjee, J., Vijayaraghavan, R., Arora, A., MacFarlane, D.R. and Patti, A.F. (2016). Lemon Juice Based Extraction of Pectin from Mango Peels: Waste to Wealth by Sustainable Approaches. ACS Sustainable Chemistry and Engineering, 4(11), 5915-5920. https://doi.org/10.1021/acssuschemeng.6b01342

Choo, C.L. and Aziz, N.A.A. (2010). Effects of banana flour and $\beta$-glucan on the nutritional and sensory evaluation of noodles. Food Chemistry, 119(1), 3440. https://doi.org/10.1016/j.foodchem.2009.05.004 
Foo, W.T., Yew, H.S., Liong, M.T. and Azhar, M.E. (2011). Influence of formulations on textural, mechanical and structural breakdown properties of cooked yellow alkaline noodles. International Food Research Journal, 18(4), 1295-1301

Goswami, G., Meena, B.D., Sharma, B., Mendiratta Sanjod, K., Pathak, Vikas, Kumar, R.R. and Talukder, S. (2017). Development of mango peel powder incorporated functional carabeef cookies. Journal of Meat Science, 12, 33-38.

Hatcher, D.W., Dexter, J.E., Anderson, M.J., Bellido, G.G. and Fu, B.X. (2009). Effect of blending durum wheat flour with hard white wheat flour on the quality of yellow alkaline noodles. Food Chemistry, 113(4), 980-988. https://doi.org/10.1016/ j.foodchem.2008.08.049

Ho, L.H. and Che Dahri, N. (2016). Effect of watermelon rind powder on physicochemical, textural, and sensory properties of wet yellow noodles. CyTA - Journal of Food, 14(3), 465-472. https://doi.org/10.1080/19476337.2015.1134672

Imran, M., Butt, M.S., Anjum, F.M. and Sultan, J.I. (2013). Chemical Profiling of Different Mango Peel Varieties. Pakistan Journal of Nutrition, 12(10), 934 -942. https://doi.org/10.3923/pjn.2013.934.942

Kang, J., Lee, J., Choi, M., Jin, Y., Chang, D., Chang, Y.H. and Lee, Y. (2017). Physicochemical and Textural Properties of Noodles Prepared from Different Potato Varieties. Preventive Nutrition and Food Science, 22(3), 246-250.

Kubomura, K. (1998). Instant noodles in Japan. Cereal Foods World, 43, 194-197.

Li, L.Y., Easa, A.M., Liong, M.T., Tan, T.C. and Foo, W.T. (2013). The use of microbial transglutaminase and soy protein isolate to enhance retention of capsaicin in capsaicin-enriched layered noodles. Food Hydrocolloid, 30(2), 495-503. https:// doi.org/10.1016/j.foodhyd.2012.07.017

Li, M., Zhang, J.-H., Zhu, K.-X., Peng, W., Zhang, S.K., Wang, B., Zhu, Y.-J. and Zhou, H.-M. (2012). Effect of superfine green tea powder on the thermodynamic, rheological and fresh noodle making properties of wheat flour. LWT - Food Science and Technology, 46(1), 23-28. https:// doi.org/10.1016/j.lwt.2011.11.005

Mellema, M. (2003). Mechanism and reduction of fat uptake in deep-fat fried foods. Trends in Food Science and Technology, 14(9), 364-373. https:// doi.org/10.1016/S0924-2244(03)00050-5

Moss, H.J., Miskelly, D.M. and Moss, R. (1986). The effect of alkaline conditions on the properties of wheat flour dough and cantonese-style noodles.
Journal of Cereal Science, 4(3), 261-268. https:// doi.org/10.1016/S0733-5210(86)80028-5

Siriamornpun, S., Tangkhawanit, E. and Kaewseejan, N. (2016). Reducing retrogradation and lipid oxidation of normal and glutinous rice flours by adding mango peel powder. Food Chemistry, 201, 160-167. https:// doi.org/10.1016/j.foodchem.2016.01.094

Sogi, D., Bhatia, R., Garg, S.K. and Bawa, A.S. (2005). Biological evaluation of tomato waste seed meals and protein concentrate. Food Chemistry, 89(1), 5356. https://doi.org/10.1016/j.foodchem.2004.01.083

Sogi, D.S., Siddiq, M., Greiby, I. and Dolan K.D. (2013). Total phenolics, antioxidant activity, and functional properties of 'Tommy Atkins' mango peel and kernel as affected by drying methods. Food Chemistry, 141(3), 2649-2655. https:// doi.org/10.1016/j.foodchem.2013.05.053

Sudha, M.L., Vetrimani, R. and Leelavathi, K. (2007). Influence of fibre from different cereals on the rheological characteristics of wheat flour dough and on biscuit quality. Food Chemistry, 100(4), 13651370.

https://doi.org/10.1016/ j.foodchem.2005.12.013

Shin, S.-Y. and Kim, S.-K. (1993). Cooking properties of dry noodles prepared from HRW-WW and HRWASW wheat flour blends. Korean Journal of Food Science and Technology, 25(3), 232-237.

Tan, T.C., Phatthanawiboon, T. and Mat Easa, A. (2016). Quality, Textural, and Sensory Properties of Yellow Alkaline Noodles Formulated with Salted Duck Egg White. Journal of Food Quality, 39(4), 342-350. https://doi.org/10.1111/jfq.12203

Yeoh, S.Y., Alkarkhi, A.F.M. and Easa, A.M. (2014). Effect of cross-linking agent on physicochemical, texture properties and microstructure of canned soy protein isolate-yellow alkaline noodles prepared by retort processing. Journal of Food Processing and Preservation, 38(3), 1187-1197. https:// doi.org/10.1111/jfpp.12079

Zhu, F. and Li, J. (2019). Physicochemical and sensory properties of fresh noodles fortified with ground linseed (Linum usitatissimum). LWT - Food Science and Technology, 101, 847-853. https:// doi.org/10.1016/j.lwt.2018.12.003 